\title{
Association of prenatal and childhood environment smoking exposure with puberty timing: a systematic review and meta-analysis
}

\author{
Yiwen Chen, Qin Liu*, Wenyan Li, Xu Deng, Bo Yang and Xin Huang
}

\begin{abstract}
Objectives: Mothers who smoke during pregnancy or while their children are small were common in some populations. Epidemiological studies have tried to detect the effect of prenatal tobacco smoke (PTS), and childhood environmental tobacco smoke (ETS) on puberty timing have not shown a consensus results. We aimed to examine current evidence and estimate the associations between PTS or/and ETS and puberty timing.

Methods: Seven databases were searched from inception to May 2017. All the cohort studies examining the associations between PTS and/or ETS and puberty timing were identified. Two reviewers independently screened all studies, evaluated the quality of eligible studies, and extracted the data. The quality assessment of the eligible cohort studies was based on the Newcastle-Ottawa Scale. Risk ratio (RR), standard mean difference (SMD), and 95\% confidence intervals (Cls) were calculated and pooled by CMA (Version 2.0, Biostat, Inc., USA).

Results: Compared with controls, girls with PTS and ETS exposure have an earlier age at menarche (SMD - 0.087, 95\% Cl 0.174 to -0.000 ), and similar results were found in both PTS subgroup (SMD $-0.097,95 \% \mathrm{Cl}-0.192$ to -0.002 ) and prospective cohort subgroup (SMD $-0.171,95 \% \mathrm{Cl}-0.253$ to -0.090$)$. And number of boys with early voice break in PTS group was significantly increasing than non-exposed boys (RR $1.34,95 \% \mathrm{Cl} 1.29$ to 1.40 ).

Conclusions: PTS exposure possibly decrease age of menarche of girls, and studies on boys were urgent needed. Appropriate and comprehensive outcome measures using unified criteria to classify puberty should be reported in future studies.
\end{abstract}

Keywords: Prenatal smoking, Childhood environment tobacco smoke, Puberty timing, Systematic reviews, Meta-analysis

\section{Background}

Advanced puberty timing has been subject to increasing interest and concern worldwide during recent years. There were evidences that early puberty was on the rise among girls in many parts of the world, such as Gambia [1], America [2-4], Western Europe [5], and for boys were inconsistent $[3,6,7]$. Early menarche in girls was a risk factor for the occurrence of morbid obesity, hypertension as well as breast and endometrial cancer [8-11]. Recent study provided strong evidence that the younger

\footnotetext{
* Correspondence: liuqin81622@163.com; liuqin@cqmu.edu.cn School of Public Health and Management, Research Center for Medicine and Social Development, Collaborative Innovation Center of Social Risks Governance in Health, Chongqing Medical University, Chongqing, China
}

girls were at menarche, the greater was their risk of premature and early menopause [12]. Although there were less research in boys, a review suggests that early puberty was also a strong risk factor for detrimental psychosocial outcomes [13]. Factors affecting early puberty can be categorized in two distinct ways: genetically determinant $[14,15]$ and non-genetically determinant [16, 17].

Smoking, in some populations, has been a widely spread non-genetic exposure, both during pregnancy and childhood. And cigarette smoking exposure included three forms: prenatal tobacco smoke (PTS), childhood environment tobacco smoke (ETS), and both PTS and ETS. In Australia, up to $80 \%$ of indigenous women smoke during pregnancy in some communities

(c) The Author(s). 2018 Open Access This article is distributed under the terms of the Creative Commons Attribution 4.0 International License (http://creativecommons.org/licenses/by/4.0/), which permits unrestricted use, distribution, and reproduction in any medium, provided you give appropriate credit to the original author(s) and the source, provide a link to the Creative Commons license, and indicate if changes were made. The Creative Commons Public Domain Dedication waiver (http://creativecommons.org/publicdomain/zero/1.0/) applies to the data made available in this article, unless otherwise stated. 
[18]. Worldwide, almost half of children were exposed to ETS [19]. Results on associations between three forms of smoking exposure and puberty timing from the past decade and more years were inconsistent. The study by Fukuda 2013 [20] reported earlier menarche in relatively young daughters with PTS exposure. However, finding by Zhang 2014 [21] showed that PTS had no effect on age of menarche of daughters. Kolasa 1998 [22] reported an earlier age at menarche related to ETS exposure, while Shrestha 2011 [23] found no association between age at menarche and ETS.

Two existing reviews studied the relationship between PTS exposure and puberty. Håkonsen 2014 [24] studied on relationship between PTS and reproductive health of adolescent including pubertal development. This review qualitatively summarized the results without meta-analysis, and it concluded that results for girls were conflicting and the number of studies for boys was sparse. Yermachenko 2015 [25] conducted a meta-analysis based on both cross-sectional studies and cohort studies to study the association between PTS exposure and age of menarche. It suggested that pregnancy smoking may decrease age at menarche.

In summary, evidences about relationship between PTS or ETS with puberty timing were inconsistent and have not been reviewed systematically so far; therefore, it is necessary to conduct a systematic review and meta-analysis to identify the associations between PTS and/or ETS and puberty timing in both girls and boys. This systematic review seeks to address this association and highlight where more research might be needed.

\section{Methods}

\section{Selection criteria}

Inclusion criteria: we included all the cohort studies examining relationship between PTS and/or ETS with puberty timing. In this study, since PTS exposure related to pregnant women, we determined "participants" as children, adolescents, and pregnant women; "exposures" as PTS and/or ETS; "control" as not exposing to PTS and/or ETS; "outcome measures" as the number of early puberty events and the age at puberty events.

Exclusion criteria: (1) not relevant to early puberty timing or precocious puberty; (2) other language except English and Chinese; (3) repetitive research (different articles published from the same study were considered as one study).

\section{Search strategy}

We searched publications from inception to May 2017 by an electronic search among seven databases including PubMed, ISI Web of science, OVID, EBSCO, VIP Database for Chinese Technical Periodicals, WangFang Data and Chinese National Knowledge Infrastructure databases, using both the MeSH terms and free terms "puberty" or "puberty timing" or "pubertal timing" or "pubertal development" or "precocious puberty" or "sexual precocity" or "sexual prematurity" or "sexual maturation" or "menarche" or "Tanner stages" or "thelarche" or "pubarche" or "spermarche" or "spermatorrhea" or "nocturnal emission" or "testis", in combination with "maternal exposure" or "prenatal exposure" or "prenatal smoking" or "prenatal tobacco smoke" or "PTS" or "in utero exposure" or "passive smoking" or "environmental tobacco smoke" or "ETS." All the retrieved publications were imported into reference-managing software (EndNote, version X7, Thomson Scientific, Stamford, CT, USA) to complete the duplicate check.

\section{Data screening and extraction}

Two reviewers (YC, WL) independently screened all the retrieved literatures by title, abstracts, and then full texts using above inclusion criteria. Cross-checking was implemented for accuracy, and differences were resolved by discussing with the third reviewer (QL) to reach an agreement.

Data extracted from included studies by using a pre-designed extraction form were as follows: (1) general information, including authors, publication year, research area; (2) study design; (3) participants characteristics, and sample size; (4) outcomes, mode, and level of tobacco exposure; (5) other factors affecting outcomes.

\section{Risk of bias assessment}

Two reviewers (YC, WL) independently evaluated the methodology quality of each eligible study according to a pre-established assessment form based on Newcastle-Ottawa Scale [26], which distributed a score of total 9 points for each study following the criteria: 4 items for selection, 1 item for comparability, and 3 items for outcome assessment. In selection and outcome categories, at most one score can be awarded to a study for each item, but for comparability, two scores can be awarded. Studies were divided into three grades by total scores, including grade A (scored 7-9, high quality), grade B (scored 4-6, moderate quality), and grade C (scored 0-3, low quality) [27]. Differences were resolved by consulting with a third reviewer $(\mathrm{QL})$.

\section{Statistical analysis}

Meta-analysis was conducted by Comprehensive Meta-Analysis (Version 2.0, Biostat, Inc., USA). The outcomes of continuous and dichotomous variables were estimated as standardized mean difference (SMD) and relative risk (RR) with 95\% confidence intervals (CIs), respectively. Heterogeneity among the results of the included studies was checked by chi-square based $Q$ test and $I^{2}$ test. When $p<0.05$ or $I^{2}>50 \%$, heterogeneity was considered and random effects model was used. Otherwise, Manter-Haenszal fixed-effects model was used. Results went for statistically significant when $p$ value less than 0.05 . We qualitatively described the main findings 
of included studies whose data cannot be extracted or which cannot be included in meta-analysis.

We conducted subgroup analysis based on exposure time (PTS and ETS), different PTS exposure levels in girls (1-9cigarettes/day, 10-19 cigarettes/day, and $\geq 20$ cigarettes/day), cohort category (prospective cohort study and retrospective cohort study), and different definitions of early menarche. For stabilization of the results, we used the leave-one-out approach to conduct sensitivity analysis of all the outcome analyses. Since the amount of included studies did not reach the quantity requirement, we did not estimate the publication bias [28].

\section{Results}

\section{Search results}

Among 7532 records identified from the seven databases and 30 records tracked from the correlative references, a total of 20 studies reported in 21 articles [23, 29-48] met the inclusion criteria were included in the qualitative synthesis. Of which, six studies cannot be included in meta-analysis; therefore, 14 studies were included in the meta-analysis finally through a strict screening process (Fig. 1).

\section{Characteristics of included studies}

Table 1 presents the main characteristics of included studies. All the included studies were published between 2004 and 2017, with the sample size ranging from 698 to 98,995 . Among those 20 studies, 8 studies were conducted in the USA, 4 were in Denmark, 3 in UK, 2 in Australia, and the other 3 studies were conducted in Iran, Canada, and France, respectively. All studies were cohort studies, of which, 16 were prospective and 4 were retrospective cohorts. Thirteen studies assessed age at menarche as main outcome, 5 studies reported numbers of girls with early menarche as main outcome, 1 study reported number of girls reached menarche, 4 studies

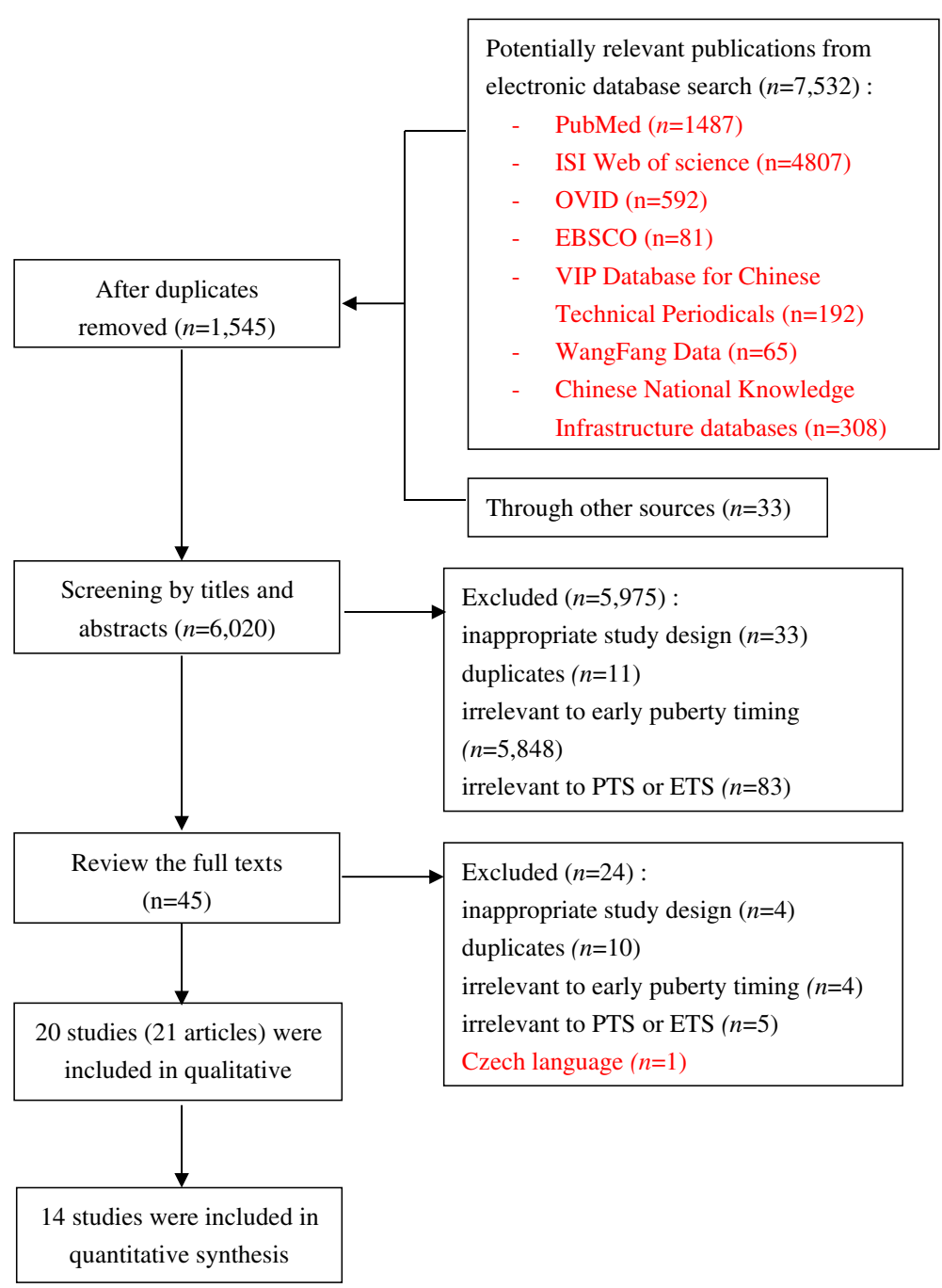

Fig. 1 Flow diagram of the literature search 
Table 1 Characteristics of Included Studies

\begin{tabular}{|c|c|c|c|c|c|c|c|c|c|}
\hline Study & Country & Gender & $\begin{array}{l}\text { Age at baseline/age at } \\
\text { follow-up surveys }\end{array}$ & $\begin{array}{l}\text { End of } \\
\text { follow-up }\end{array}$ & $\begin{array}{l}\text { Sample size } \\
\text { (expose/control }^{\mathrm{b}} \text { ) }\end{array}$ & $\begin{array}{l}\text { Exposure } \\
\text { type }^{c}\end{array}$ & $\begin{array}{l}\text { PTS exposure } \\
\text { level }\end{array}$ & $\begin{array}{l}\text { Primary } \\
\text { outcomes }\end{array}$ & $\begin{array}{l}\text { Cohort } \\
\text { category }\end{array}$ \\
\hline $\begin{array}{l}\text { Håkonsen } \\
2013 \text { [29] }\end{array}$ & Denmark & Boys & $\begin{array}{l}\text { Prenatal/ } \\
18-21 \text { years old }\end{array}$ & 18-21 years old & $858 / 1387$ & PTS & $\begin{array}{l}\text { Past smoker }{ }^{d} \\
1-9 \text { cigs/day } \\
10-14 \text { cigs/day } \\
\geq 15 \text { cigs/day }\end{array}$ & $\begin{array}{l}\text { Age at acne } \\
\text { Age at voice break } \\
\text { Age at regular shaving } \\
\text { Age at first } \\
\text { nocturnal emission }\end{array}$ & Prospective \\
\hline $\begin{array}{l}\text { Ernst } \\
2012 \text { [30] }\end{array}$ & Denmark & Girls & $\begin{array}{l}\text { Prenatal/ } \\
19-21 \text { years old }\end{array}$ & $\begin{array}{l}\text { Onset of } \\
\text { menarche }\end{array}$ & $129 / 220$ & PTS & $\begin{array}{l}1-9 \text { cigs/day } \\
\geq 10 \text { cigs/day }\end{array}$ & Age at menarche & Prospective \\
\hline $\begin{array}{l}\text { Windham } \\
2008[31]\end{array}$ & USA & Girls & $\begin{array}{l}\text { Prenatal/ } \\
\text { (1) up to } 7 \text { or } 8 \text { years old } \\
\text { (2) } 20 \text { s or } 27-33 \text { years }\end{array}$ & $\begin{array}{l}\text { Onset of } \\
\text { menarche }\end{array}$ & $832 / 722$ & $\begin{array}{l}\text { PTS and } \\
\text { ETS }\end{array}$ & $\begin{array}{l}<10 \mathrm{cigs} / \text { day } \\
10-19 \mathrm{cigs} / \text { day } \\
\geq 20 \mathrm{cigs} / \text { day }\end{array}$ & Age at menarche & Prospective \\
\hline $\begin{array}{l}\text { Ferris } \\
2010 \text { [32] } \\
\text { Terry } \\
2009 \text { [33] }\end{array}$ & USA & Girls & $\begin{array}{l}\text { Prenatal/ } \\
\text { (1) up to } 7 \text { years old } \\
\text { (2) } 38-46 \text { years old }\end{array}$ & $\begin{array}{l}\text { Onset of } \\
\text { menarche }\end{array}$ & $\begin{array}{l}\text { C1: } 98 / 150 \\
\text { C2: } 90 / 61 \\
\text { C3: } 95 / 61\end{array}$ & $\begin{array}{l}\text { PTS and } \\
\text { ETS }\end{array}$ & $\begin{array}{l}1-9 \text { cigs/day } \\
10-19 \text { cigs/day } \\
\geq 20 \text { cigs/day }\end{array}$ & $\begin{array}{l}\text { No. of girls with } \\
\text { early menarche }\end{array}$ & Prospective \\
\hline $\begin{array}{l}\text { Behie } \\
2015 \text { [34] }\end{array}$ & Australia & Girls & $\begin{array}{l}\text { Prenatal/ } \\
12-13 \text { years old }\end{array}$ & $12-13$ years old & $222 / 1271$ & PTS & $\begin{array}{l}\text { Smoking most } \\
\text { days; } \\
\text { smoking } \\
\text { occasionally }\end{array}$ & $\begin{array}{l}\text { Age at menarche } \\
\text { No. of girls reached } \\
\text { menarche }\end{array}$ & Prospective \\
\hline $\begin{array}{l}\text { Windham } \\
2004 \text { [35] }\end{array}$ & USA & Girls & $\begin{array}{l}\text { Prenatal/ } \\
\text { (1) } 5 \text { years old } \\
\text { (2) 9-11 years old } \\
\text { (3) } 15-17 \text { years old }\end{array}$ & 16 or 17 years old & $\begin{array}{l}\text { C1: 508/214, } \\
\text { C2: } 162 / 214 \\
\text { C3: } 417 / 214\end{array}$ & $\begin{array}{l}\text { PTS and } \\
\text { ETS }\end{array}$ & $\begin{array}{l}1-9 \mathrm{cigs} / \text { day } \\
10-19 \mathrm{cigs} / \text { day } \\
\geq 20 \mathrm{cigs} / \text { day }\end{array}$ & $\begin{array}{l}\text { No. of girls with } \\
\text { early menarche }\end{array}$ & Prospective \\
\hline $\begin{array}{l}\text { Tehrani } \\
2014[36]\end{array}$ & Iran & Girls & $\begin{array}{l}\text { Prenatal/ } \\
\text { evaluated once } \\
\text { every } 3 \text { years }\end{array}$ & $\begin{array}{l}\text { Onset of } \\
\text { menarche }\end{array}$ & $34 / 367$ & ETS & Not mentioned & Age at menarche & Prospective \\
\hline $\begin{array}{l}\text { Rubin } \\
2009 \text { [37] }\end{array}$ & UK & Girls & $\begin{array}{l}\text { Prenatal/evaluated once } \\
\text { yearly from } 8 \text { to } 11 \text { years }\end{array}$ & 11 years old & $368 / 2159$ & PTS & Not mentioned & $\begin{array}{l}\text { No. of girls with } \\
\text { early menarche }\end{array}$ & Prospective \\
\hline $\begin{array}{l}\text { Shrestha } \\
2011[23]\end{array}$ & Denmark & Girls & $\begin{array}{l}\text { Prenatal/ } \\
\text { (1) 15-18 years old } \\
\text { (2) 18-21 years old }\end{array}$ & $\begin{array}{l}\text { Onset of } \\
\text { menarche }\end{array}$ & $656 / 970$ & $\begin{array}{l}\text { PTS and } \\
\text { ETS }\end{array}$ & $\begin{array}{l}\text { Stop smoking } \\
\text { sometimes } \\
\text { during pregnancy; } \\
1-9 \text { cigs/day; } \\
\geq 10 \text { cigs/day }\end{array}$ & Age at menarche & Prospective \\
\hline $\begin{array}{l}\text { Maisonet } \\
2010[38]\end{array}$ & UK & Girls & $\begin{array}{l}\text { Prenatal/ } \\
8-14 \text { years old }\end{array}$ & $\begin{array}{l}\text { Onset of } \\
\text { menarche }\end{array}$ & $647 / 2657$ & PTS & Not mentioned & $\begin{array}{l}\text { Age at menarche } \\
\text { Age at breast } \\
\text { development stage } \\
\geq 2 \text { and } \geq 3 \\
\text { Age at pubic hair } \\
\text { development stage } \\
\geq 2 \text { and } \geq 3\end{array}$ & Prospective \\
\hline $\begin{array}{l}\text { Fried } \\
2001 \text { [39] }\end{array}$ & Canada & $\begin{array}{l}\text { Boys } \\
\text { and } \\
\text { girls }\end{array}$ & $\begin{array}{l}\text { Prenatal/evaluated once } \\
\text { yearly up to } 8 \text { years, } \\
\text { thereafter, every } 3 \text { years }\end{array}$ & $13-16$ years old & Not mentioned & PTS & $\begin{array}{l}\text { Up to } 16 \mathrm{mg} \\
\text { nicotine/day; } \\
\geq 16 \mathrm{mg} \\
\text { nicotine/day }\end{array}$ & $\begin{array}{l}\text { Age at menarche } \\
\text { Age at breast began } \\
\text { to develop } \\
\text { Age at start shaving } \\
\text { Age at voice break }\end{array}$ & Prospective \\
\hline $\begin{array}{l}\text { Wang } \\
2012[40]\end{array}$ & USA & Girls & $\begin{array}{l}\text { Prenatal/evaluated } \\
\text { once yearly from } \\
10 \text { to } 15 \text { years old }\end{array}$ & $\begin{array}{l}\text { Onset of } \\
\text { menarche }\end{array}$ & $21 / 284$ & PTS & Not mentioned & $\begin{array}{l}\text { Age at menarche } \\
\text { Age of breast } \\
\text { developmentstage } 1 \text { or } \\
2 \text { and } 3 \\
\text { Age of pubic hair } \\
\text { developmentstage } 1 \text { or } \\
2 \text { and } 3\end{array}$ & Prospective \\
\hline $\begin{array}{l}\text { Flom } \\
2017 \text { [41] }\end{array}$ & USA & Girls & $\begin{array}{l}\text { Prenatal/ infancy, } \\
\text { early childhood } \\
\text { and adulthood }\end{array}$ & $\begin{array}{l}\text { Onset of } \\
\text { menarche }\end{array}$ & $647 / 443$ & PTS & Not mentioned & $\begin{array}{l}\text { No. of girls with } \\
\text { early menarche }\end{array}$ & Prospective \\
\hline $\begin{array}{l}\text { Dossus } \\
2012[42]\end{array}$ & France & Girls & $\begin{array}{l}\text { 40-65 years old/ } \\
\text { Prenatal }\end{array}$ & - & $802 / 75,171$ & $\begin{array}{l}\text { PTS and } \\
\text { ETS }\end{array}$ & Not mentioned & Age at menarche & Retrospective \\
\hline $\begin{array}{l}\text { Hart } \\
2009 \text { [43] }\end{array}$ & Australia & Girls & $\begin{array}{l}\text { Prenatal } / 2,6,8, \\
10,13 / 14, \text { and } \\
16 / 17 \text { years old }\end{array}$ & $\begin{array}{l}\text { Onset of } \\
\text { menarche }\end{array}$ & $47 / 184$ & PTS & Not mentioned & $\begin{array}{l}\text { Age at menarche } \\
\text { No. of girls with } \\
\text { breast development stage3 } \\
\text { No. of girls with pubic } \\
\text { hairdevelopmentstage2/3 }\end{array}$ & Prospective \\
\hline $\begin{array}{l}\text { Morris } \\
2010 \text { [44] }\end{array}$ & UK & Girls & 16-30 years old/prenatal & - & $630 / 5710$ & PTS & Not mentioned & Age at menarche & Retrospective \\
\hline \multirow{2}{*}{$\begin{array}{l}\text { D'Aloisio } \\
2013 \text { [45] }\end{array}$} & USA & Girls & Not mentioned/prenatal & - & $11,029 / 21,067$ & PTS & Not mentioned & Age at menarche & Retrospective \\
\hline & Denmark & Boys & Not mentioned/prenatal & - & PTS:1385/2101 & & Not mentioned & & Retrospective \\
\hline
\end{tabular}


Table 1 Characteristics of Included Studies (Continued)

\begin{tabular}{|c|c|c|c|c|c|c|c|c|c|}
\hline Study & Country & Gender & $\begin{array}{l}\text { Age at baseline/age at } \\
\text { follow-up surveys }\end{array}$ & $\begin{array}{l}\text { End of } \\
\text { follow-up }\end{array}$ & $\begin{array}{l}\text { Sample size } \\
(\text { expose/control } \\
\left.\text { b }^{a}\right)\end{array}$ & $\begin{array}{l}\text { Exposure } \\
\text { type }^{c}\end{array}$ & $\begin{array}{l}\text { PTS exposure } \\
\text { level }\end{array}$ & $\begin{array}{l}\text { Primary } \\
\text { outcomes }\end{array}$ & $\begin{array}{l}\text { Cohort } \\
\text { category }\end{array}$ \\
\hline $\begin{array}{l}\text { Ravnborg } \\
2011[46]\end{array}$ & & & & & ETS:769/1332 & $\begin{array}{l}\text { PTS and } \\
\text { ETS }\end{array}$ & & $\begin{array}{l}\text { No. of boys with } \\
\text { early voice break } \\
\text { No. of boys with } \\
\text { early growth of penis } \\
\text { No. of boys with early } \\
\text { pubic hair development }\end{array}$ & \\
\hline $\begin{array}{l}\text { Carter } \\
2014[47]\end{array}$ & USA & Girls & $\begin{array}{l}\text { Prenatal/ } \\
14 \text { years old }\end{array}$ & 14 years old & $168 / 97$ & PTS & Not mentioned & Age at menarche & Prospective \\
\hline $\begin{array}{l}\text { Liu } \\
2010 \text { [48] }\end{array}$ & USA & Girls & $\begin{array}{l}\text { Prenatal/ } \\
1,4,7,18 \text { years old }\end{array}$ & $\begin{array}{l}\text { Onset of } \\
\text { menarche }\end{array}$ & $486 / 308$ & PTS & $\begin{array}{l}1-19 \mathrm{cigs} / \text { day } \\
\geq 20 \mathrm{cigs} / \text { day }\end{array}$ & $\begin{array}{l}\text { No. of girls with } \\
\text { early menarche }\end{array}$ & Prospective \\
\hline
\end{tabular}

a PTS prenatal tobacco smoke, ETS childhood environment tobacco smoke. C1 PTS/control, C2 ETS/control, C3 both PTS and ETS/control

${ }^{b}$ Control group: non-smoker group

'Exposure type included 3 types:(1) PTS, (2) ETS, (3) both PTS and ETS

${ }^{\mathrm{d}}$ Past smoker, included women who smoked before pregnancy or stopped sometime before 36th gestational week

Early puberty occurred was defined according to age at menarche, $\leq 12$ years for early menarche

fEarly puberty occurred was defined according to age at menarche, $<12$ years for early menarche

${ }^{g}$ Early puberty occurred was defined according to age at menarche, $\leq 11$ years for early menarche

hEarly puberty occurred was defined according to age at menarche, $<11$ years for early menarche

reported breast development, 4 studies reported pubic hair development, and another 3 studies reported puberty events in boys. Seventeen studies focused only on girls, 2 studies were only on boys, and the other 1 included both boys and girls. Data collection methods in included studies contained questionnaires, clinical records, face-to-face interviews, and body measurements. The exposure type in included studies contained PTS exposure only, ETS exposure only, and both PTS and ETS exposure. For the PTS exposure, the levels of exposure were also extracted when possible.

\section{Risk of bias in included studies}

Thirteen out of 20 included studies were evaluated as high-quality research, scored 7-9, while another 7 were evaluated as moderate quality research, scored 6 (Table 2). All studies had adequate representativeness of the exposed cohort, exposure ascertainment, and selection of control. All outcomes of interest were not presented at the start of prospective cohort study. For comparability, 8 out of 20 studies considered both the main confounding factors and others, like maternal BMI and maternal age at menarche. Outcome assessments of all studies were satisfied. Subjects of 12 prospective studies were followed until the outcomes occurred, while the other 4 studies were not followed up sufficiently. Loss is inevitable in cohort study and 7 out of 16 prospective cohort studies had a rate of lost to follow-up below $20 \%$.

\section{Data synthesis}

Age at menarche

Age at menarche in PTS or ETS group Data on age at menarche of girls who exposed to PTS or ETS were provided in seven studies [23, 36, 38, 40, 42-44]. The pooled data showed that age at menarche in girls with
PTS and ETS exposure (SMD - 0.087, 95\% CI - 0.174 to $-0.000, I^{2}=52.813 \%, 87,309$ girls) was significantly lower than control group, and similar results were found in PTS subgroup (SMD - 0.097, 95\% CI -0.192 to -0.002 , $I^{2}=67.069 \%, 86,153$ girls). There was no significantly difference in age of menarche between ETS subgroup (SMD - 0.037, 95\% CI -0.251 to $0.177, I^{2}=0.000 \%, 1156$ girls) and control group. The random effects model was adopted because of heterogeneity among studies (Fig. 2).

For the five studies reporting PTS exposure, we conducted the cohort-categories subgroup analysis. We found that age at menarche in prospective cohort subgroup (SMD $-0.171,95 \%$ CI -0.253 to $-0.090, I^{2}=0.000 \%$, 3840 girls) was significantly lower than control group. No significantly difference was found in age of menarche between retrospective cohort subgroup (SMD - 0.128, 95\% CI -0.194 to $0.062, I^{2}=76.303 \%, 82,313$ girls) and control group (see Additional file 1: Figure S1). In the sensitivity analysis, the pooled results altered when removing Maisonet 2010 [38] (SMD - 0.046, 95\% CI -0.097 to $0.004,84,005$ girls).

Two included studies cannot be included in the meta-analysis. D'Aloisio 2013 [45] divided the children into five age groups according to their age at menarche $(\leq 10$, $11,12-13,14, \geq 15$ years old) and compared the relative risk ratios for early and late menarche in association with prenatal smoking exposure. It did not report the exact age at menarche for the girls and cannot be included in the meta-analysis. It found that PTS associated with early menarche (RR 1.13, 95\% CI 1.03 to 1.24, 32,095 girls).

Carter 2014 [47] found no significant relationship between age at menarche and PTS $(r$ 0.17, $p>0.05,265$ girls), but did not report the sample of girls who exposed to PTS and had onset of menarche.

Age at menarche in different PTS exposure levels Data on age at menarche of girls who exposed to different 


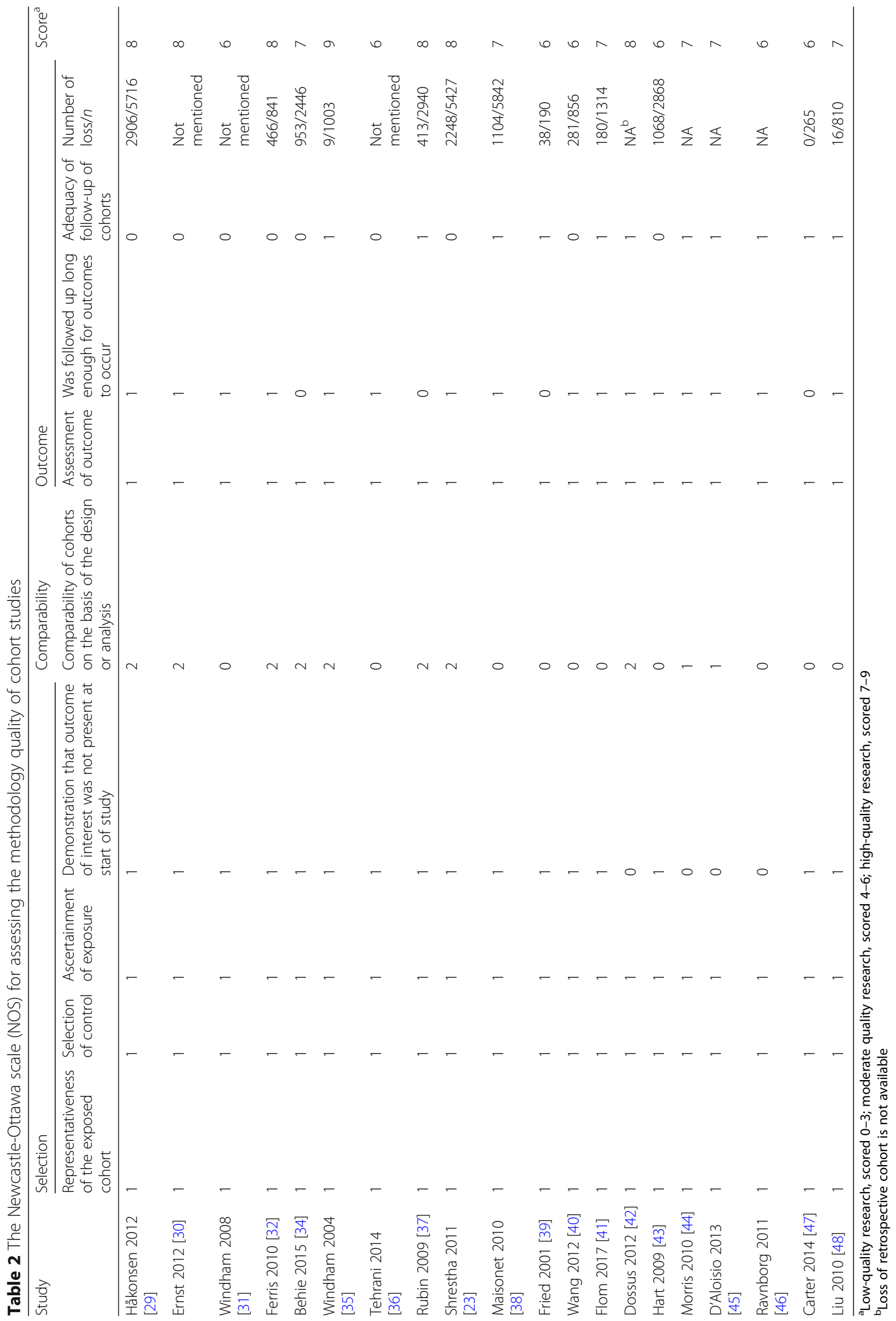




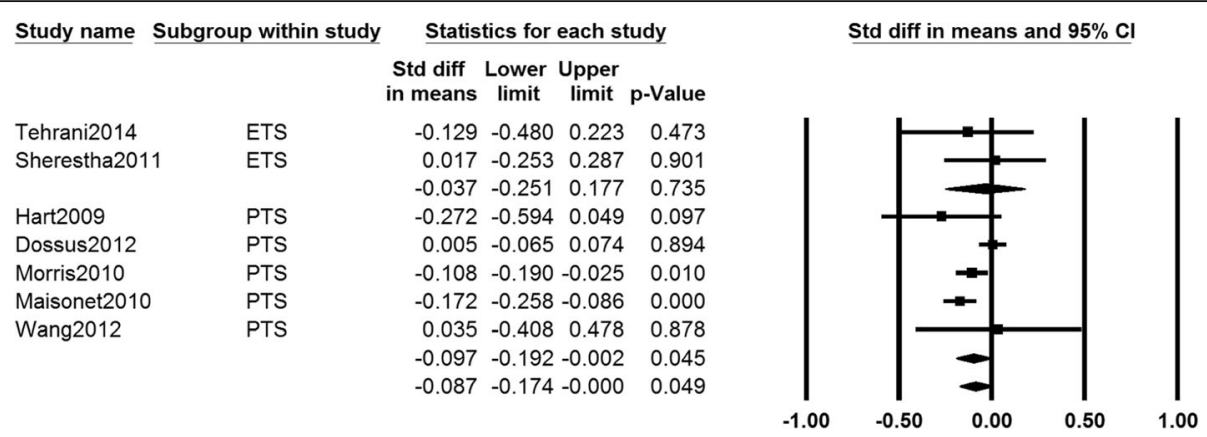

Fig. 2 Forest plot for the age at menarche between the PTS or ETS group and control group

PTS levels were provided in three studies [23, 30, 31]. The subgroup analysis showed that there were no significant differences between different PTS exposure levels and control groups in age at menarche (SMD - 0.085, 95\% CI -0.273 to $0.103,2633$ girls, for $1-9$ cigs/day subgroup; SMD $-0.296,95 \%$ CI -0.628 to $0.037,1556$ girls, for $\geq 10$ cigs/day subgroup, $\left.I^{2}=77.730 \%\right)$. The random effects model was adopted because of heterogeneity among studies (Fig. 3).

Behie 2015 [34] mentioned that with non-smoking mothers used as the reference level, mothers who reported smoking cigarettes 'most days' during gestation showed an HR of 1.40 (95\% CI 1.10-1.79), which suggested that prenatal smoke exposure increase the chance of an earlier age at menarche.

\section{Number of girls with early menarche}

Number of girls with early menarche in PTS or ETS group Data on number of girls with early menarche who exposed to PTS or ETS were provided in five studies [30, 32, 37, 41, 48]. The pooled data showed that number of girls with early menarche under PTS or ETS exposure (RR $0.649,95 \%$ CI 0.794 to $1.154, I^{2}=60.541 \%$, 5819 girls) was not significantly different from that in control group, and similar results were found in PTS subgroup (RR 0.737, 95\% CI 0.806 to $1.356, I^{2}=68.362 \%$,
5292 girls) and ETS subgroup (RR 0.872, 95\% CI 0.667 to $1.140, I^{2}=9.575 \%, 527$ girls). Random effects model was adopted in the meta-analysis (Fig. 4).

For the five studies reporting PTS exposure, we conducted the subgroup analysis by the definition of early menarche. We found that number of girls in subgroup of early menarche defined as $\leq 11$ years (RR $1.377,95 \%$ CI 1.086 to $1.745, I^{2}=0.000 \%, 3321$ girls) was significantly more in PTS exposure group than control group, while no significantly difference was found in number of girls in subgroup of early menarche defined $\leq 12$ (RR $0.900,95 \%$ CI 0.708 to $1.145, I^{2}=46.688 \%, 1971$ girls) between two group (see Additional file 2: Figure S2).

And Behie 2015 [34] indicated the number of girls reached menarche (RR 1.276, 95\% CI 1.154 to 1.411 , $P=0.000,1493$ girls) was significantly higher in PTS exposure group than that in control group.

Number of girls with early menarche exposed to both PTS and ETS Two studies [30,32] provided data about number of girls with early menarche exposed to both PTS and ETS. The pooled data showed that number of girls with early menarche with both PTS and ETS exposure (RR $0.934,95 \%$ CI 0.575 to $1.516, I^{2}=74.0 \%, 180$ girls) was not significantly different from that in control group, and the random effects model was adopted because of the high heterogeneity (Fig. 5).

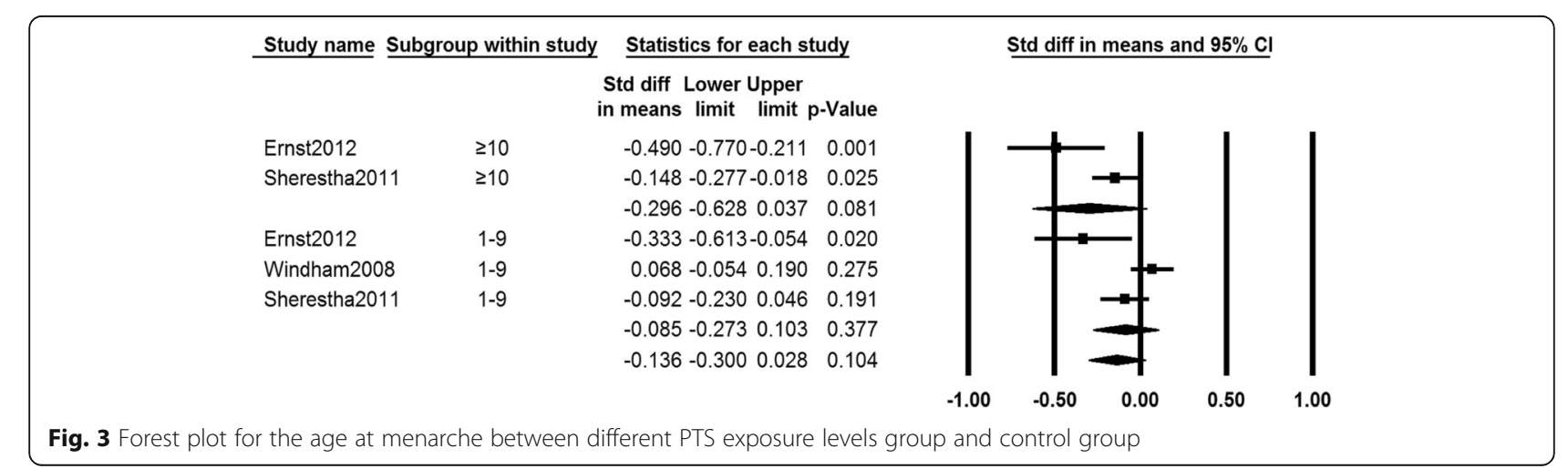




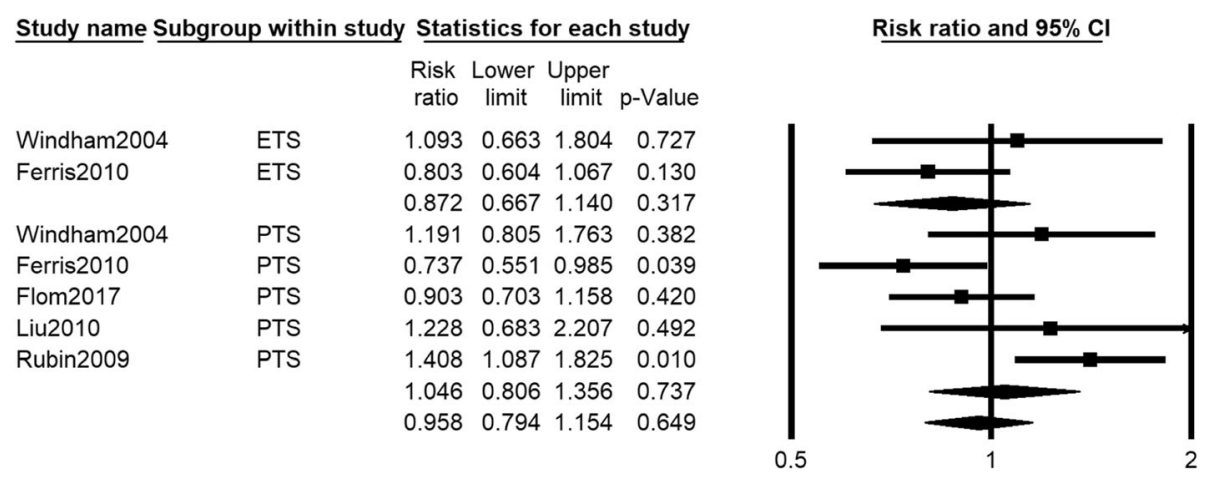

Fig. 4 Forest plot for the number of girls with early menarche between the PTS or ETS group and control group

Number of girls with early menarche in different PTS exposure levels Two studies [30,32] provided data about number of girls with early menarche who exposed to different PTS levels. The pooled data showed that there were no significant differences between different PTS exposure level groups and control groups in the number of girls with early menarche (RR $0.990,95 \% \mathrm{CI}$ 0.751 to 1.305 , 644 girls, for $1-9$ cigs/day subgroup; RR $0.964,95 \%$ CI 0.692 to $1.344,479$ girls, for 10-19cigs/ day subgroup; RR $0.966,95 \%$ CI 0.695 to 1.343 , 575 girls, for $\geq 20$ cigs/day subgroup, $I^{2}=3.17 \%$ ). The fixed-effects model was adopted (Fig. 6).

\section{Puberty index in boys}

Three studies [29, 39, 46] reported different puberty index of boys exposed to PTS. In Håkonsen 2013 [29], age at acne, voice break, regular shaving, and first nocturnal emission in boys with PTS exposure were not significantly different from that in control group in either of the four exposure level groups (Table 3), and similar results were found in number of boys with early growth of penis and early pubic hair development in Ravnborg 2011 [46]. But the number of boys with early voice break with PTS exposure (RR 1.34, 95\% CI 1.29 to 1.40, 2478 boys) was significantly higher than control group (Table 4).

Fried 2001 [39] reported that an ANOVA of the age at which the boy's voices began to change indicated that the higher level of prenatal smoking was associated with earlier onset of this pubertal indicant $[F(2.61)=7.82, P<0.01]$, and the onset of shaving has the same trend emerged with as the voice change data.

\section{Discussions}

For all we know, this is the first systematic review and meta-analysis of the relationship between PTS and/or ETS exposure and puberty timing of both girls and boys. We found two reviews about PTS and puberty; one of which conducted a qualitative description, reporting a hypothesis of increasing risk of puberty onset in boys and girls with PTS exposure. The other meta-analysis about PTS and age of menarche in girls suggested that PTS exposure may accelerate onset of age of menarche. Findings in these two reviews were relatively coincident with our results of PTS and age of menarche in girls or voice break onset in boys. Comparing with the previous two reviews, our study has a wider scope of tobacco exposure mode (both PTS and ETS) and included both genders. Besides, not only age of menarche, but also number of girls with early puberty events, number of boys with early puberty events, age at various puberty events were analyzed in this study. In addition, studies conducted in both developing and developed countries were included in the review, involving Asian population.

In present study, we found that PTS was possibly and negatively associated with age of menarche in girls, which suggested that mothers smoking during pregnancy may accelerate the onset of menarche of daughters. But this result was not stable enough, when removing out Maisonet 2010 [38], it turned to no association. Given the high heterogeneity, studies in PTS

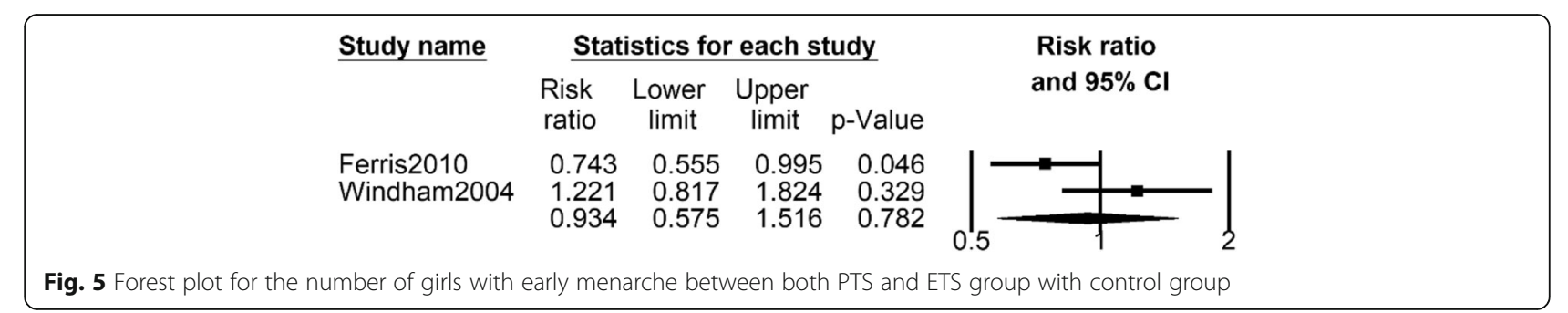




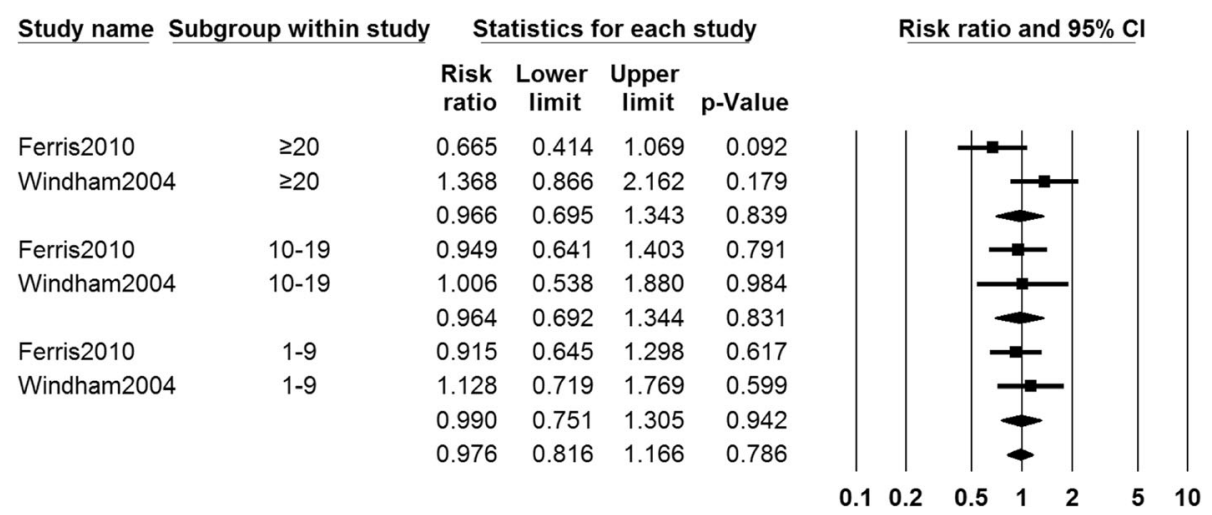

Fig. 6 Forest plot for the number of girls with early menarche between different PTS exposure levels group and control group

group were analyzed by cohort type in the subgroup analysis, and the heterogeneity dropped from 67.069 to $0.000 \%$ in prospective cohort subgroup, which suggested that study design may be one of the main sources of heterogeneity in PTS group. Prospective cohort study has a better demonstrated effectiveness which shows that the conclusion of early menarche with PTS is well founded.

While the results showed that there is no statistical significance on association between ETS and age of menarche, which may not necessarily mean that there is no relationship between them. As fewer studies reported ETS and puberty timing, the exact conclusion cannot be given exactly, which calls for more high-quality studies to confirm the relationship.

Table 3 Mean difference (MD) and 95\%Cl of age at four puberty index of boys with different PTS exposure levels in Håkonsen 2013

\begin{tabular}{llll}
\hline Puberty index & PTS exposure level & $\mathrm{MD}$ & $95 \% \mathrm{Cl}$ \\
\hline Age at acne & Past smoker & 0.10 & $0.08,0.28$ \\
& $1-9$ cigs/day & 0.10 & $-0.05,0.25$ \\
& $10-14$ cigs/day & -0.10 & $-0.28,0.08$ \\
& $\geq 15$ cigs/day & -0.20 & $-0.43,0.03$ \\
& Past smoker & 0.00 & $-0.17,0.17$ \\
Age at voice break & $1-9$ cigs/day & 0.10 & $-0.04,0.24$ \\
& $10-14$ cigs/day & -0.10 & $-0.27,0.07$ \\
& $\geq 15$ cigs/day & -0.10 & $-0.32,0.12$ \\
Age at regular shaving & Past smoker & 0.10 & $-0.08,0.28$ \\
& $1-9 c i g s /$ day & 0.00 & $-0.15,0.15$ \\
& $10-14$ cigs/day & 0.00 & $-0.18,0.18$ \\
& $\geq 15$ cigs/day & 0.10 & $-0.13,0.33$ \\
Age at first nocturnal emission & Past smoker & 0.00 & $-0.22,0.22$ \\
& $1-9$ cigs/day & 0.10 & $-0.09,0.29$ \\
& $10-14$ cigs/day & -0.10 & $-0.32,0.12$ \\
& $\geq 15$ cigs/day & -0.20 & $-0.49,0.09$ \\
\hline
\end{tabular}

There was no strong evidence that PTS or ETS is associated with the number of girls with early menarche. The possible reason may be the differences in cut-offs for early menarche. There were four definitions for early menarche in the five studies [32, 35, 37, 41, 48]: $\leq 12$, < $12, \leq 11,<11$ years respectively. When early menarche defined as $\leq 11$ years, the number of girls with early menarche in PTS group was significantly more than that in control group, and the heterogeneity also decreased when we conducted subgroup analysis by definition of early menarche.

Results from three studies on the association between PTS and puberty development in boys showed consistent results. Fried 2001 [39] reported an earlier age of voice break and shaving onset among boys exposed to PTS, which was based on a small cohort without confounder adjustment. The large retrospective study by Ravnborg 2011 [46] showed that exposed boys experienced an earlier voice break without confounder adjustment. The latest prospective study by Håkonsen 2012 [29] reported tendencies toward earlier age at acne, voice break, regular shaving, and first nocturnal emission, which indicated that boys exposed to PTS had earlier onset of puberty. However, no statistically significant differences were found with several important potential confounders adjusted. And no data provided can be used in meta-analysis in above studies. Therefore, the association between PTS exposure and puberty in boys could not be inferred. More studies reporting unified and

Table 4 Risk ratio (RR) and 95\%Cl of number of boys with early puberty index development with PTS exposure in Ravnborg 2011

\begin{tabular}{llll}
\hline Puberty index & RR & $95 \% \mathrm{Cl}$ & $p$ \\
\hline $\begin{array}{l}\text { Number of boys with } \\
\text { early voice break }\end{array}$ & 1.34 & $1.29,1.40$ & 0.00 \\
$\begin{array}{l}\text { Number of boys with } \\
\text { early growth of penis }\end{array}$ & 0.99 & $0.94,1.04$ & 0.64 \\
$\begin{array}{l}\text { Number of boys with } \\
\text { early pubic hair development }\end{array}$ & 0.99 & $0.93,1.04$ & 0.60 \\
\hline
\end{tabular}


complete outcome measures need to be conducted in boys to confirm the association.

The mechanism by which smoking exposure influence puberty timing is not clear enough yet. While 4000 chemicals contained over cigarettes, nicotine reduced blood flow to the placenta and fetus in pregnant smokers [18], and heavy metal cadmium led a retardation of trophoblastic outgrowth and development of placental [19]. Studies of animals and humans suggested that PTS exposure alter production of sex hormones and gonadotrophins [22-24], which are all crucial chemicals in puberty onset. For females, PTS exposure may potentially impact primordial follicle number at puberty and uterine volume [20]. And both PTS and ETS exposure to nicotine resulted in delayed ovarian dysfunction in adult female offspring [21]. For males, several large studies reported that moderate or heavy smoking in pregnancy reduced the testis size and sperm count of male offspring in adult by $20-40 \%[49,50]$.

Studies included in the systematic review were conducted in four continents, namely, North America, Europe, Oceania, and Asia with multiethnic. To a certain extent, the results of this systematic review remind parents of the tobacco exposure effect on their children.

We carried out the research in strict accordance with the criterion of systematic review. However, there are still some limitations. First, though we tried to contact with the original authors to obtain necessary data of the included studies, six studies failed to obtain data required for meta-analysis. Among them, three $[29,39,46]$ reported different puberty events of boys, respectively, and three $[34,45,47]$ reported age of menarche did not provide sufficient data for meta-analysis. Failure to merge data above may lead to inaccuracy of results. Besides, one potential study in Czech was excluded, which may lead to selection bias.

Second, the assessment of methodology quality showed that scores of comparability and adequacy of follow-up of cohorts were relatively low; therefore, future research should pay more attention to these above aspects. Third, the main outcome measure of girls was menarche onset. Other outcomes cannot be conducted in meta-analysis due to few reports of tanner stage, inconsistent standard of division of staging and early onset. Meanwhile, reports of exposure levels were also limited and had different division standard, which made it difficult to find the dose-effect relationship.

Fourth, heterogeneity that comes from criteria of smoking exposure levels, race diversity, regional diversity, and sample size difference could not be analyzed in the current analysis. Fifth, few included studies reported the association of puberty development and PTS or ETS in boys, therefore need more studies to confirm this association. Finally, 4 out of 16 prospective cohort studies we included have not used the onset of outcome as the end of follow-up, so that children who have not occurred onset of puberty were excluded from the data analysis in these studies, which may lead to the loss of information and affect the accuracy of the results.

\section{Conclusion}

In summary, the findings of this systematic review suggested that PTS exposure possibly decrease age of menarche of girls; there was still instability. No association were identified between ETS or different PTS levels with age of menarche, or PTS and/or ETS with number of girls with early puberty, or different PTS levels with number of girls with early puberty. As for boys, relationship between puberty timing with PTS or ETS remains to be further investigated with more high-quality cohort studies. Future studies should also provide appropriate and comprehensive outcome measures using unified definition to classify early or normal puberty for better comparison.

\section{Additional files}

Additional file 1: Figure S1. Forest plot of dividing PTS group by cohort categories. (DOC $75 \mathrm{~kb}$ )

Additional file 2: Figure S2. Forest plot of dividing PTS group by the definition of early menarche. (DOC 69 kb)

\section{Abbreviations}

Cls: Confidence intervals; ETS: Childhood environment tobacco smoke; PTS: Prenatal tobacco smoke; RR: Relative risk; SMD: Standardized mean difference

\section{Acknowledgements}

The authors are grateful to Walter Rogan and Yan Wang from National Institute of Environmental Health Sciences and Fahimeh Ramezani Tehrani from Reproductive Endocrinology Research Center, Research Institute for Endocrine Sciences, Shahid Beheshti University of Medical Sciences for providing data we need.

\section{Funding}

The National Youth Science Fund Project of China (grant 81502825) and Basic and Frontier Research Project of Chongqing Science and Technology Commission (grant cstc2013jcyjA10001) provided financial assistance.

\section{Availability of data and materials}

Please contact author for data requests.

\section{Authors' contributions}

QL, Y-WC, and W-YL conceived and designed the review. Y-WC, W-YL, XD, $\mathrm{BY}$, and $\mathrm{XH}$ established search strategies. Y-WC, W-YL, and $\mathrm{QL}$ selected and extracted the data. Y-WC, W-YL, XD, BY, XH, and QL performed the statistical analysis. Y-WC and QL drafted and revised the manuscript. All authors read and approved the final manuscript.

Ethics approval and consent to participate Not applicable.

Consent for publication

Not applicable.

Competing interests

The authors declare that they have no competing interests. 


\section{Publisher's Note}

Springer Nature remains neutral with regard to jurisdictional claims in published maps and institutional affiliations.

Received: 27 February 2018 Accepted: 28 June 2018

Published online: 18 July 2018

\section{References}

1. Prentice S, Fulford AJ, Jarjou LM, Goldberg GR, Prentice A. Evidence for a downward secular trend in age of menarche in a rural Gambian population. Ann Hum Biol. 2010;37(5):717-21.

2. Euling SY, Herman-Giddens ME, Lee PA, Selevan SG, Juul A, Sørensen T, et al. Examination of US puberty-timing data from 1940 to 1994 for secular trends: panel findings. Pediatrics. 2008;121(3):172-91.

3. Lee PA, Guo SS, Kulin HE. Age of puberty: data from the United States of America. APMIS. 2001;109(103):81-8.

4. Aksglaede L, Sørensen K, Petersen JH, Skakkebaek NE, Juul A. Recent decline in age at breast development: the Copenhagen Puberty Study. Pediatrics. 2009;123(5):932-9.

5. Tanner JM. Growth at adolescence: with a general consideration of the effects of hereditary and environmental factors upon growth and maturation from birth to maturity, vol. 2. Oxford: Blackwell Scientific Publications; 1962. p. 326.

6. Karpati AM, Rubin CH, Kieszak SM, Marcus M, Troiano RP. Stature and puberta stage assessment in American boys: the 1988-1994 third National Health and Nutrition Examination Survey. J Adolesc Health. 2002;30(3):205-12.

7. Reiter EO, Lee PA. Have the onset and tempo of puberty changed? Arch Pediatri Adolesc Med. 2011;155(9):988-9.

8. Neves AG, Kasawara KT, Godoymiranda AC, Oshika FH, Chaim EA, Surita FG. Early menarche and teenager pregnancy as risk factors for morbid obesity among reproductive-age women: a case-control study. Clinics. 2017;72(9):547-53.

9. Bubach S, Loret CDM, Hardy R, Dreyfus J, Santos AC, Horta BL. Early menarche and blood pressure in adulthood: systematic review and metaanalysis. J Public Health. 2017;(Suppl(1)):1-9.

10. Collaborative Group on Hormonal Factors in Breast Cancer. Menarche, menopause, and breast cancer risk: individual participant meta-analysis, including 118964 women with breast cancer from 117 epidemiological studies. Lancet Oncol. 2012;13(11):1141-51.

11. Carwile JL, Willett WC, Spiegelman D, Hertzmark E, Rich-Edwards J, Frazier AL Michels KB. Sugar-sweetened beverage consumption and age at menarche in a prospective study of US girls. Hum Reprod. 2015;30(3):675-83.

12. Mishra GD, Pandeya N, Dobson AJ, Chung HF, Anderson D, Diana K, Sandin S, Giles GG, Bruinsma F, Hayashi K, Lee JS, Mizunuma H, Cade JE, Burley V, Greenwood DC, Goodman A, Simonsen MK, Adami HO, Demakakos P, Weiderpass E. Early menarche, nulliparity and the risk for premature and early natural menopause. Hum Reprod. 2017;32(3):679-86.

13. Mendle J, Ferrero J. Detrimental psychological outcomes associated with pubertal timing in adolescent boys. Dev Rev. 2012;32(1):49-66.

14. Towne B, Czerwinski SA, Demerath EW, Blangero J, Roche AF, Siervogel RM. Heritability of age at menarche in girls from the Fels longitudinal study. Am J Phys Anthropol. 2005;128(1):210-9.

15. Zacharias L, Wurtman RJ. Age at menarche: genetic and environmental influences. N Engl J Med. 1969;280(16):868-75.

16. Yermachenko A, Dvornyk V. Nongenetic determinants of age at menarche: a systematic review. Biomed Res Int. 2014;2014(1):371583.

17. Buluş AD, Aşci A, Erkekoglu P, Balci A, Andiran N, Koçer-Gümüşel B. The evaluation of possible role of endocrine disruptors in central and peripheral precocious puberty. Toxicol Mech Methods. 2016;26(7):493-500.

18. Gould GS, Bar-Zeev Y, Bovill M, Atkins L, Gruppetta M, Clarke MJ, et al. Designing an implementation intervention with the Behaviour Change Wheel for health provider smoking cessation care for Australian indigenous pregnant women. Implement Sci. 2017;12(1):114

19. Oberg M, Jaakkola MS, Woodward A, Peruga A, Prüss-Ustün A. Worldwide burden of disease from exposure to second-hand smoke: a retrospective analysis of data from 192 countries. Lancet. 2011:377(9760):139-46.

20. Fukuda M, Fukuda K, Shimizu T, Nobunaga M, Byskov AG, Andersen CY. Maternal smoking during pregnancy and age at menarche of premenopausal and postmenopausal daughters. Hum Reprod. 2013;28(2):551-2.

21. Zhang Z, Hartman TJ. Birth weight is associated with age at menarche in US girls. Clin Pediatr. 2014;53(1):82-5.
22. Kolasa E, Hulanicka B, Waliszko A. Does exposure to cigarette smoke influence girls' maturation? Przegl Epidemiol. 1998;52(3):339-50.

23. Shrestha A, Nohr EA, Bech BH, Ramlau-Hansen $\mathrm{CH}$, Olsen J. Smoking and alcohol use during pregnancy and age of menarche in daughters. Hum Reprod. 2011;26(1):259-65.

24. Håkonsen LB, Ernst A, Ramlau-Hansen CH. Maternal cigarette smoking during pregnancy and reproductive health in children: a review of epidemiological studies. Asian J Androl. 2014;16(1):39-49.

25. Yermachenko A, Dvornyk V. A meta-analysis provides evidence that prenatal smoking exposure decreases age at menarche. Reprod Toxicol. 2015:58:222-8.

26. Wells G, Shea BO, O'Connell D, Peterson J, Welch V, Losos M. The Newcastle-Ottawa scale (NOS) for assessing the quality of nonrandomized studies in Meta-analysis. Appl Eng Agric. 2014;18(6):727-34.

27. Ownby RL, Crocco E, Acevedo A, John V, Loewenstein D. Depression and risk for Alzheimer disease: systematic review, meta-analysis, and meta regression analysis. Arch Gen Psychiatry. 2006;63(5):530-8.

28. Sutton AJ, Duval SJ, Tweedie RL, Abrams KR, Jones DR. Empirical assessment of effect of publication bias on meta-analyses. BMJ. 2000;320(7249):1574-7.

29. Håkonsen LB, Olsen J, Støvring H, Ernst A, Thulstrup AM, Zhu JL. Maternal cigarette smoking during pregnancy and pubertal development in sons. A follow-up study of a birth cohort. Andrology. 2013;1(2):348-55.

30. Ernst A, Kristensen SL, Toft G, Thulstrup AM, Håkonsen LB, Olsen SF. Maternal smoking during pregnancy and reproductive health of daughters: a follow-up study spanning two decades. Hum Reprod. 2012;27(12):3593-600.

31. Windham GC, Zhang L, Longnecker MP, Klebanoff M. Maternal smoking, demographic and lifestyle factors in relation to daughter's age at menarche. Paediatr Perinat Epidemiol. 2008;22(6):551-61.

32. Ferris JS, Flom JD, Tehranifar P, Mayne ST, Terry MB. Prenatal and childhood environmental tobacco smoke exposure and age at menarche. Paediatr Perinat Epidemiol. 2010;24(6):515-23.

33. Terry MB, Ferris JS, Tehranifar P, Wei Y, Flom JD. Birth weight, postnatal growth, and age at menarche. Am J Epidemiol. 2009:170(1):72-9.

34. Behie AM, O'Donnell MH. Prenatal smoking and age at menarche: influence of the prenatal environment on the timing of puberty. Hum Reprod. 2015; 30(4):957-62.

35. Windham GC, Bottomley C, Birner C, Fenster L. Age at menarche in relation to maternal use of tobacco, alcohol, coffee, and tea during pregnancy. Am J Epidemiol. 2004;159(9):862-71.

36. Ramezani Tehrani F, Mirmiran P, Gholami R, Gholami R, Moslehi N, Azizi F, et al. Factors influencing menarcheal age: results from the cohort of Tehran lipid and glucose study. Int J Endocrinol Metab. 2014;12(3):16130.

37. Rubin C, Maisonet M, Kieszak S, Monteilh C, Holmes A, Flanders D, et al. Timing of maturation and predictors of menarche in girls enrolled in a contemporary British cohort. Paediatr Perinat Epidemiol. 2009;23(5):492-504.

38. Maisonet M, Christensen KY, Rubin C, Holmes A, Flanders WD, Heron J, et al. Role of prenatal characteristics and early growth on pubertal attainment of British girls. Pediatrics. 2010;126(3):591-600.

39. Fried PA, James DS, Watkinson B. Growth and pubertal milestones during adolescence in offspring prenatally exposed to cigarettes and marihuana. Neurotoxicol Teratol. 2001;23(5):431-6.

40. Wang Y, Dinse GE, Rogan WJ. Birth weight, early weight gain and pubertal maturation: a longitudinal study. Pediatr Obes. 2012:7(2):101-9.

41. Flom JD, Cohn BA, Tehranifar P, Houghton LC, Wei Y, Protacio A, et al. Earlier age at menarche in girls with rapid early life growth: cohort and within sibling analyses. Ann Epidemiol. 2017;27(7):187-93.

42. Dossus L, Kvaskoff M, Bijon A, Fervers B, Boutron-Ruault MC, Mesrine S, et al. Determinants of age at menarche and time to menstrual cycle regularity in the French E3N cohort. Ann Epidemiol. 2012;22(10):723-30.

43. Hart R, Sloboda DM, Doherty DA, Norman RJ, Atkinson HC, Newnham JP, et al. Prenatal determinants of uterine volume and ovarian reserve in adolescence. J Clin Endocrinol Metab. 2009:94(12):4931-7.

44. Morris DH, Jones ME, Schoemaker MJ, Ashworth A, Swerdlow AJ. Determinants of age at menarche in the UK: analyses from the breakthrough generations study. Br J Cancer. 2010;103(11):1760-4

45. D'Aloisio AA, DeRoo LA, Baird DD, Weinberg CR, Sandler DP. Prenatal and infant exposures and age at menarche. Epidemiology. 2013;24(2):277-84.

46. Ravnborg TL, Jensen TK, Andersson AM, Toppari J, Skakkebaek NE, Jørgensen N. Prenatal and adult exposures to smoking are associated with adverse effects on reproductive hormones, semen quality, final height and body mass index. Hum Reprod. 2011;26(5):1000-11. 
47. Carter RC, Jacobson JL, Dodge NC, Granger DA, Jacobson SW. Effects of prenatal alcohol exposure on testosterone and pubertal development. Alcohol Clin Exp Res. 2014;38(6):1671-9.

48. Liu T, Gatsonis CA, Baylin A, Buka SL. Prenatal exposure to cigarette smoke and benign breast disease. Epidemiology. 2010;21(5):736-43.

49. Sharpe RM. Environmental/lifestyle effects on spermatogenesis. Philos Trans R Soc Lond Ser B Biol Sci. 2010;365(1546):1697-712.

50. Jensen TK, Jørgensen N, Punab M, Haugen TB, Suominen J, Zilaitiene B, $t$ al. Association of in utero exposure smoking with reduced semen quality and testis size in adulthood: a crosssectional study of 1,770 young men from the general population in five European countries. Am J Epidemiol. 2004;159(1):49-58.

Ready to submit your research? Choose BMC and benefit from:

- fast, convenient online submission

- thorough peer review by experienced researchers in your field

- rapid publication on acceptance

- support for research data, including large and complex data types

- gold Open Access which fosters wider collaboration and increased citations

- maximum visibility for your research: over $100 \mathrm{M}$ website views per year

At BMC, research is always in progress.

Learn more biomedcentral.com/submissions 